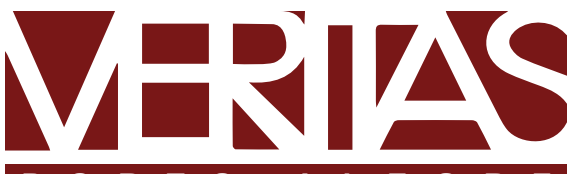

$\begin{array}{llllllllllll}P & O & R & T & O & A & L & E & G & R & E\end{array}$

\title{
O FENÔMENO DA IDOLATRIA: UM DIÁLOGO TEOLÓGICO E FILOSÓFICO
}

\author{
The phenomenon of idolatry: \\ a theological and philosophical dialogue \\ El fenómeno de la idolatría: \\ un diálogo teológico y filosófico
}

Jair Inácio Tauchen'

Pontifícia Universidade Católica do Rio Grande do Sul, Porto Alegre, RS, Brasil.

\section{Resumo}

A pesquisa apresenta o fenômeno da "idolatria" através de um diálogo interdisciplinar entre teologia e a filosofia. $\mathrm{O}$ aporte conceitual examina a idolatria enquanto expressão da divindade que oprime e exige a imolação de sacrifícios humanos. O problema consiste em saber se a idolatria acontece somente através do culto aos ídolos ou pode se desenvolver mesmo sem imagens? A idolatria consiste em qualquer realidade divinizada pelo homem. Ela constitui-se ao substituir o divino por algo que a represente. Enfim, a idolatria esconde e legitima a opressão, especialmente, dos mais pobres, causando assimetrias e exclusão social.

Palavras-chave: Idolatria. Deuses. Ídolos. Imagens

Doutor e Pós-doutorando (PNPD/CAPES) em Filosofia pela Pontifícia Universidade Católica do Rio Grande do Sul (PUCRS), Porto Alegre, RS, Brasil. ORCID: http://orcid.org/0000-00021974-016X.E-mail: jairtauchen@gmail.com 


\begin{abstract}
The research presents the phenomenon of "idolatry" through an interdisciplinary dialogue between theology and philosophy. The conceptual contribution examines idolatry as an expression of the deity that oppresses and demands the immolation of human sacrifices. The problem is whether idolatry happens only through worshiping idols or can develop even without images? Idolatry consists of any reality divinized by man. It is constituted by replacing the divine with something that represents it. Finally, idolatry hides and legitimizes oppression, especially the poorest, causing asymmetries and social exclusion.
\end{abstract}

Keywords: Idolatry. Gods. Images. Idols.

\title{
Resumen
}

La investigación presenta el fenómeno de la "idolatría” a través de un diálogo interdisciplinario entre teología y filosofía. La contribución conceptual analiza la idolatría como una expresión de la divinidad que oprime y exige la inmolación de sacrificios humanos. El problema consiste justamente en saber si la idolatría ocurre sólo a través de la adoración a los ídolos o puede desarrollarse incluso sin imágenes? La idolatría consiste en cualquier realidad divinizado por el hombre. Ella se constituye al reemplazar a la divinidad por algo que le representa. En fin, la idolatría oculta y legitima la opresión, especialmente, de los más pobres, provocando asimetrías y exclusión social.

Palabras clave: Idolatría. Dioses. Ídolos. Imágenes.

\section{Introdução}

O tema da idolatria na teologia bíblica é muito abrangente; está presente no Judaísmo e no Cristianismo². Por conseguinte, é necessário estabelecer fundamentos claros para poder interpretar os textos bíblicos, muitas vezes restritivos e violentos, mediante uma análise respeitosa das diversidades espirituais que fazem parte da vida do homem. A prática religiosa da idolatria permeia o processo do politeísmo e monoteísmo do

2 O artigo é um excerto da tese de doutorado do próprio autor: Por uma crítica da idolatria em articulação com a teologia e a economia - um diálogo interdisciplinar, defendida em 2018 na Pontifícia Universidade Católica do Rio Grande do Sul. 
Antigo Testamento e do Novo Testamento ${ }^{3}$ Ela está diretamente ligada ao significado de denúncia, repulsa, intolerância, discriminação e condenação dos cultos que utilizam imagens, o que permite uma interpretação ampla. Essa interpretação, muitas vezes tida como fundamentalista e religiosamente intolerante, é um grande desafio para a sociedade atual marcada pela emergência das diversidades culturais, religiosas e de orientação sexual.

Considerando a abrangência do tema na teologia bíblica, o propósito do artigo é analisar a idolatria como uma estrutura que oprime e exige entrega e sacrifícios da vida humana. Por isso, diante das inúmeras narrativas bíblicas, faz-se necessário escolher algumas que exibem ídolos como deuses que legitimam a opressão, apoiam poderes dominadores, interferem na comunidade humana e são incapazes de ouvir o clamor dos pobres ${ }^{4}$.

Na tradição cristã, o ídolo ou culto dos ídolos encontra-se no sentido oposto ao culto do verdadeiro Deus proclamado pelas escrituras. O mesmo ocorre em relação à fé, pois se o reconhecimento do Deus verdadeiro depende da fé e o culto a Deus apenas pode acontecer a partir da fé, a idolatria aproxima-se da incredulidade. Assim, o verdadeiro culto a Deus é incompatível ao deus dinheiro ou ao deus mercado que, por sua vez, deve ser compreendido como idolatria. O idólatra guarda dinheiro e bens somente para si, um culto como se fosse deus. Comportamento reprovado pelo Evangelho quando se refere a servir a Deus e ao dinheiro ao mesmo

\footnotetext{
3 O Antigo Testamento comparado com o Novo possui uma abordagem sobre a idolatria muito maior. No Novo Testamento os Evangelhos e os outros livros praticamente não abordam o tema de forma patente, mas consta em alguns relatos no Atos, em alguns escritos paulinos e no Apocalipse de maneira mais elaborada. Beale (2014, p. 28) questiona se em razão disso é possível "concluir que o problema da idolatria cessara ou deixara de ser tão agudo na história posterior de Israel na época de Jesus, ou então que não era problema na igreja do primeiro século?".

4 O sociólogo e filósofo alemão Erich Fromm (1983, p. 123) entende o processo idolátrico da seguinte forma: "a essência do que era chamado 'idolatria' pelos antigos profetas não está em o homem adorar muitos deuses em vez de um único. Está em os ídolos serem a obra das mãos do próprio homem - eles são coisas e, no entanto, o homem curva-se ante a elas e as reverencia; adora aquilo que ele mesmo criou. Ao fazê-lo ele se transforma em coisa. Transfere às coisas de sua criação os atributos da vida e, em vez de experenciar-se como pessoa criadora, só entra em contato consigo mesmo através da adoração do ídolo. Ele se alheou às forças de sua própria vida, à riqueza de suas próprias potencialidades, e só entra em contato consigo mesmo de maneira indireta, e submetendo-se à vida congelada nos ídolos".
} 
tempo. Jesus, ao afirmar que não é possível prestar culto simultaneamente a Deus e a Mamon (Mt 6,24), renova o que os profetas do Antigo Testamento já haviam denunciado. No Novo Testamento o enfoque da idolatria continua atual: "Mamon", nesse caso, refere-se aos bens que as pessoas acumulam e não utilizam. Quem se utiliza disso como sentido da vida, não considera a Palavra de Deus, vive sob o mando da idolatria. A ganância pelo dinheiro deve ser desmascarada em sua imagem de justiça.

Os teólogos latino-americanos, ao criticarem as relações do mercado no contexto econômico, são impulsionados a considerar a Sagrada Escritura como elemento balizador a fim de interpretar o mundo que os cerca e fundamentar a questão da idolatria. Por isso, o termo "ídolo" deve expressar um significado maior do que apenas uma imagem ou estátua. A idolatria pode ser qualquer realidade divinizada pelo homem. Sempre que o homem substitui o poder divino por outra confiança, cai em idolatria. As possibilidades são inúmeras, por exemplo, a divinização do poder, do Estado, das raças, do capital.

A idolatria no sentido econômico e empresarial tem algo diferente da idolatria na Bíblia. O mercado, o dinheiro e o capital são criações humanas, são ídolos adorados que se tornam insaciáveis. O verdadeiro Deus segundo a tradição bíblica quer que o ser humano ocupe o centro da história com suas necessidades concretas atendidas. De outro modo, os ídolos do mercado, do dinheiro, estão ligados à exploração e à injustiça na sociedade; diferente do Deus que se tornou humano em Jesus de Nazaré que não ordena sacrifício algum, os ídolos do mercado exigem sacrifícios. Aliás, Ele próprio se entregou como sacrifício, no Cristianismo.

\section{0 problema da idolatria: imagem ou ídolo?}

No Antigo Testamento em Gênesis 1, relata-se que Deus criou o ser humano à sua imagem e semelhança, capaz de refletir a sua gloria. A questão é saber se no decorrer da história até a atualidade esse propósito foi cumprido. O que o homem como criatura de Deus reflete atualmente? O ser humano, conforme a narrativa bíblica, foi criado para refletir Deus e quando isso não acontece reflete outra coisa. Reflete, sobretudo, aquilo 
com o qual está comprometido, seja com o Deus criador ou com qualquer outro objeto da criação. Assim, quando não adora o Deus verdadeiro em vez de assemelhar-se com Ele, o idólatra assemelha-se com o ídolo que adora. O problema da idolatria, considerando a revelação bíblica do primeiro e do segundo mandamento, é que ele camufla a nobreza entre Deus, o Criador e a criatura. O fato de representar Deus por alguma imagem divina o desvia da verdadeira natureza espiritual. Ou seja, criar outros deuses e tirar o Deus do seu devido lugar é diminuir a glória do Criador.

Adão e Eva foram criados à imagem de Deus com o propósito de refletir sua glória e povoar a terra com essa finalidade. Ao abandonar o compromisso com Deus, deixaram de refletir sua imagem e passaram a reverenciar outra coisa no lugar de Deus. Trocaram a reverência ao Deus criador por outro objeto de adoração. Idolatria é adorar qualquer coisa a não ser Deus. Adão trocou a lealdade a Deus pela fidelidade a ele próprio e a satanás, refletindo características da serpente.

O fato de Adão refletir no princípio a imagem de Deus, revela um conceito antigo até mesmo fora dos limites de Israel. Por exemplo, na Síria e no Egito era comum colocar imagens de divindades no templo dos quais os reis eram imagens vivas do deus, o próprio reflexo desse deus. Destarte, justifica-se a fabricação das imagens com metais nobres com a finalidade de refletir a glória do deus que representavam. O rei era a imagem viva do deus.

A Bíblia contém inúmeras passagens condenando o culto que envolve a utilização de imagens, que incita atos de violência, que discrimina e emprega a intolerância em nome de Deus. A questão das imagens/ídolos esteve presente no conflito entre católicos e reformados; esteve e está presente nas discussões conturbadas entre o cristianismo e as religiões africanas e indígenas; na relação do hinduísmo com outras religiões que utilizam imagens em seus templos. O termo geralmente é utilizado no sentido de demonizar ou diminuir a dignidade das religiões, um processo discriminatório e violento que pesa sobre as religiões dos povos africanos e povos originários das Américas, mediante uma infeliz interpretação de um possível respaldo na "Palavra de Deus", especialmente em textos do Antigo Testamento. 
A religião de Israel 5 utilizou por muitos séculos imagens de todos os tipos, formas e tamanhos representando deuses e deusas nos cultos, tanto nos centros urbanos, como nas vilas camponesas. Migrou de um complexo sistema politeísta para um monoteísmo centralizado em Jerusalém como único local de culto e com um único código litúrgico. Somente no período da Judeia como província do Império Persa é que o monoteísmo, culto sem imagem, tornou-se oficial em Judá. ${ }^{6}$

A utilização de imagens nos cultos públicos e santuários foi comum até aproximadamente $720 \mathrm{a}$. C. quando ocorreu a reforma de Ezequias e Josias. Fato comprovado pelas escavações arqueológicas que encontraram inúmeras imagens relacionadas a esse período; algo também comprovado pelos textos bíblicos que empregam certa naturalidade e por não esboçar nenhuma crítica ao se referir à utilização das imagens nos cultos religiosos (Gn 31,19. 34. 35; Jz 17,5; 18,14-20; 1Sm 19, 13-16). A proibição das imagens entra em vigor após as reformas de Ezequias e de Josias (Dt 7,25-26; 16,21-22).

Sobre o emprego do termo ídolo ou imagem relacionados à Bíblia, Dietrich (2015, p. 346) chama atenção para a sua tradução para o português. Geralmente a tradução carrega uma conotação pejorativa e depreciativa envolvendo o objeto como algo condenável, especialmente quando na fase politeísta, antes das reformas de Ezequias e Josias, o texto bíblico depara-se com alguma imagem utilizada no culto público: "muitas traduções usam ou acrescentam a palavra 'ídolo' para traduzir palavras que no hebraico indicam simplesmente alguma 'imagem'." Quando se faz referência isolada à palavra "imagem", o seu significado é neutro, não está imbuído de nenhuma carga negativa e pejorativa, diferente do significado de "ídolo". Dietrich (2015, p. 346) apresenta um exemplo: na religião católica ou mesmo nas religi-

\footnotetext{
5 Segundo Dietrich (2015, p. 342), a história de Israel não começou em 1800 a. C. na Babilônia com a migração de Abraão como tradicionalmente é conjecturado. Teve início bem mais tarde entre 1500 e 1300 a. C. em Canaã. Neste período ocorreu a sedentarização de algumas famílias de pastores em três regiões montanhosas da Palestina: Siquém, Betel e Hebron. Todo esse território fazia parte da região conhecida na época como Canaã.
}

6 Alguns textos bíblicos do Antigo Testamento que mencionam a utilização de imagens em cultos: Gn 31, 19.30-35; Is 6, 1-13; Iz 6,24-30; 1Sm 19,13-16; 1Rs 12,28-29; 2Rs 18,4; 23,4-14; Jr 44, 15-19. 
ões afro-brasileiras uma pessoa pode dizer: "na cabeceira da minha cama tenho três imagens", mas é improvável que dirá: "na cabeceira da minha cama tenho três ídolos." O mesmo é válido para os terreiros de candomblé, umbanda, batuques e outras religiões que utilizam imagens em seus cultos; elas não irão se referir a essas imagens chamando-as de "ídolos". Portanto, a religião de Israel no período pré-exílico quando faz referência à utilização de imagens em cultos, não pode ser interpretada como "idolatria".

Essa interpretação é comum nas traduções. Empregam a palavra ídolo na tradução portuguesa da palavra hebraica que se refere a objetos, mas que no texto bíblico transmite a simples indicação de uma imagem. É oportuno apresentar mais alguns exemplos sugeridos por Dietrich (2015, p. 346-347) que comprovam o problema da tradução. O texto bíblico utilizado para análise é Gn 31,19:

Bíblia de Jerusalém (BJ): "Labão fora tosquiar os rebanhos e Raquel roubou os ídolos domésticos que pertenciam a seu pai."

A Bíblia da CNBB: "Como Labão tinha ido à tosquia das ovelhas, Raquel roubou as estatuetas dos ídolos de seu pai."

Tradução ecumênica da Bíblia (TEB): "Laban tinha ido tosquiar o seu gado e Raquel roubou os ídolos que pertenciam a seu pai."

Bíblia de Estudo Almeida: "Tendo ido Labão fazer a tosquia das ovelhas, Raquel furtou os ídolos do lar que pertenciam a seu pai."

A Nova Versão Internacional (NVI) Bíblia de Estudo Arqueológica: “Enquanto Labão tinha saído para tosquiar suas ovelhas, Raquel roubou os ídolos do clã.

No hebraico o versículo citado não tem nenhuma palavra que possa ser traduzida como "ídolo". Segundo Dietrich (2015, p. 347), "o texto menciona a palavra terafim e o faz com a maior naturalidade. Terafim era o nome dado às imagens dos deuses domésticos que muito provavelmente eram os ancestrais divinizados de cada família, eram os Elohim das famílias." Todas as famílias tinham seu Elohim (Gn 31,53). Portanto, nesse texto bíblico não existe conotação de crítica à posse das imagens em cultos familiares porque para os autores dessa narrativa a utilização de imagens era comum 
e, consequentemente, elas não possuem o significado de ídolos. A tradução da palavra terafim do hebraico para o português com o significado de "ídolos" "revela que os tradutores assimilaram as proposições das reformas de Ezequias ( $720 \mathrm{aC}$ ) e de Josias ( $620 \mathrm{aC}$ ), e as têm como verdadeiras revelações da vontade de Javé." (DIETRICH, 2015, p. 347). Porém, utilizaram de forma retroativa em tradições anteriores às reformas de Ezequias e de Josias. Quando as traduções apresentam a palavra "ídolos" onde não existe e nem pressupõe esse significado no texto hebraico estão criando um anacronismo que mascara o período politeísta de Israel antes das reformas?

As reformas centralizadoras de Ezequias e Josias (i) estabeleceram o templo de Jerusalém como único local de culto em Israel; (ii) designa Javé como Deus de Israel; (iii) proíbe o culto a qualquer outra divindade; (iv) condena o uso de imagem que represente Javé ou qualquer outra divindade. A partir dessa reforma, todas as imagens passam a ser consideradas ídolos e, por conseguinte, são tidas como crime de idolatria.

A idolatria acontece somente através do culto aos ídolos ou pode se desenvolver mesmo sem imagens? A crítica às imagens ocorre mais em função do tipo do culto, da religião e das consequências a que estão associadas do que das imagens em si. Dietrich (2015, p. 349), entende que pode haver "idolatria" sem necessariamente haver imagens. A questão da idolatria transcende à questão das imagens. Como exemplo, é conveniente recorrer a uma das respostas mais claras de toda a Escritura, representada pelo Salmo 115, 4-8:

São de prata e ouro os ídolos deles, e foram feitos por mãos humanas; esses têm boca e não falam, têm olhos e não veem,

\footnotetext{
7 Nesse sentido, Dietrich (2015, p. 349) entende que "esse procedimento acaba também por falsear ou até mesmo esvaziar completamente o sentido libertador da crítica à idolatria. Pois acaba focando o peso dessa crítica no uso da imagem em si. Idolatria nesse caso é possuir imagens, usar imagens como representação do Divino, substituir o Divino por algo que se possa manipular, usar. Mas não é esse o motivo original da crítica profética às imagens na Bíblia."
} 


\begin{abstract}
têm ouvidos e não escutam, têm nariz e não cheiram; têm mãos e não apalpam, têm pés e não andam, nem sua garganta produz sussurro algum. Os ídolos deles são obras de mãos humanas.
\end{abstract}

O que o salmo condena não é o fato de as imagens serem de "ouro e prata, feitas por mãos humanas" que se caracterizam pela imobilidade $\mathrm{e}$ insensibilidade, mas, sobretudo, o fato de denunciar aqueles que produzem e confiam nessas imagens. Aqueles que fabricam e adoram os ídolos ficarão igual a esses ídolos e o castigo será tornarem-se semelhantes a eles: "têm olhos e não veem". Ou seja, não ouvem e não veem as coisas do espírito, mesmo tendo um deus por trás deles, ficaram tão cegos e tão surdos espiritualmente quanto esses ídolos. A idolatria, nesse caso, expressa uma religiosidade enganadora e revela que o maior pecado de Israel foi a idolatria. O ídolo nada mais é do que uma obra "feita por mãos humanas", um produto da vontade do homem que tem "boca, olhos, ouvido, nariz, mãos, pés, garganta" (Salmo 115, 4-8), semelhante a uma estátua inanimada. ${ }^{8} \mathrm{Ou}$, nas palavras do apóstolo Paulo, quando comenta em I Cor 12,2 o referido Salmo, chama os ídolos de "mudos" seguindo a polêmica da falta de comunicação, pois "não têm boca e não falam".

A crítica de que os ídolos não têm vida está amparada no fato de que os fabricantes e adoradores acreditavam que os deuses falam e ensinam por meio dos ídolos, mas na verdade dentro da imagem somente existe

\footnotetext{
8 Nesse sentido é oportuno o comentário de Beale (2014, p. 21): “[...] quando se retratam os ídolos com olhos e orelhas que não enxergam nem ouvem, afirma-se que seus adoradores têm olhos e orelhas, mas não veem nem ouvem". O homem foi criado por Deus para ser uma criatura refletora. Portanto, vai refletir aquilo com que está comprometido, pode ser o Deus verdadeiro ou alguma imagem criada. O Salmo 115, 4-8 tem muita semelhança com a narrativa de Is 6, 1-13. Outro fato interessante segundo Beale (2014, p. 48) é que sempre que o povo de Israel é "mencionado como quem 'têm olhos para ver, mas não veem, têm ouvidos para ouvir, mas são capazes de ouvir' (ou textos semelhantes a esse) ele está sendo condenado e castigado por ser idólatra.
} 
o vazio. Confiar e seguir esses deuses é seguir no caminho tortuoso, é tornar-se semelhante aos ídolos ocos espiritualmente.

Duas outras passagens bíblicas do Antigo Testamento merecem uma atenção especial, em virtude da condenação das imagens correspondentes aos "deuses de metal fundido" e os "deuses de ouro e prata". Novamente, o contexto de proibir exclusivamente um tipo específico de imagens remete ao período anterior às reformas.

Ex 20,23: "vocês não farão para mim deuses de prata e deuses de ouro, vocês não farão para vocês".

Ex 34,17: "deuses de metal fundido não farás para ti".

Dietrich (2015, p. 352) chama atenção para dois aspectos nesses versículos. O primeiro é que são chamados de "deuses" tanto as imagens de "metal fundido" como as de "prata e ouro". É importante frisar que em nenhum momento transparece uma conotação pejorativa; não são chamados de ídolos e não sugere uma palavra com termo neutro como "imagem". Para o autor da narrativa, essas imagens são "deuses" mesmo expressando uma condenação. Nesse caso, no que diz respeito a interpretar imagens no sentido de deuses, o argumento encontra amparo em Gn 31,30 quando Labão ao procurar os seus Terafins questiona: "por que roubaste meus deuses?"9

Outro aspecto interessante é que a proibição aponta especificamente um tipo de imagem. Em Ex 20,23 proíbem-se as imagens feitas de "prata e ouro"; é bem provável que esse versículo determine a crítica mais antiga aos deuses de prata e os deuses de ouro. A narrativa em Ex 34,17 proíbe somente as de "metal fundido". Diante disso, é possível deduzir que as imagens de cerâmica, pedra, madeira ou outro material não são proibidas.

Em Ex 20,22-26 é possível encontrar outra passagem na qual uma proibição é bem específica. Nessa narrativa, a proibição de fazer "deuses de prata e deuses de ouro" está ligada à proibição de fazer "altar de pedras

\footnotetext{
9 Aqui, novamente, o sentido dos "deuses" deve ser interpretado como Elohim, ancestrais divinizados e amplamente utilizados por todas as famílias. Não existe uma conotação pejorativa ou repressiva no versículo ao utilizar a expressão "deuses".
} 
lavradas". Esses versículos tratam das primeiras tradições da redação do Código da Aliança, quando ainda era possível levantar altar fora de Jerusalém e não existia uma centralização do culto, portanto, anterior às reformas de Ezequias e Josias. Na primeira parte, o Código deixa claro que tipo de altar é permitido. São permitidos altares de terra e pedras naturais. E, também, o tipo de altar que não é permitido fazer: o de pedras lavradas. Assim, é possível perceber que a mesma especificidade de proibir "deuses de prata e deuses de ouro" está presente na proibição do altar de "pedras lavradas".

Agora é necessário perguntar: onde estavam localizados esses altares? É adequado apresentar a interpretação de Dietrich (2015, p. 353) segundo a qual "somos levados a concluir que estas proibições ecoam algumas das primeiras críticas da profecia camponesa (Amós, Oseias) contra o uso da religião para explorar os camponeses". Para tornar o argumento ainda mais claro, chama atenção para a especificidade da proibição. São proibidos deuses de metal fundido, deuses de prata e deuses de ouro. Conclui-se que as imagens de pedra, de madeira e de cerâmica estão autorizadas. Mas por que somente as de metal são proibidas? Primeiro é preciso saber quem são e onde se encontram os que podem fazer imagens de prata, de ouro e construir altares de pedras lavradas? Segundo Dietrich (2015, p. 353), as perguntas têm a mesma resposta: "eram encontrados nas principais cidades. Talvez somente nas capitais e nas cidades com 'santuários do rei' (Am 7,13)". Fica claro que esse tipo de culto é característico das cidades. A justificativa é que os materiais empregados são caros e precisam ser importados, como também, os artesãos que dominam a técnica. Isso somente é possível através da riqueza e do poder adquiridas às custas da opressão dos camponeses que viviam e trabalhavam nas proximidades das muralhas das cidades. ${ }^{10}$

\footnotetext{
10 É oportuna a interpretação de Dietrich (2015, p. 353): "estes versículos ecoam os primeiros gritos dos camponeses contra o uso da religião para explorá-los. É no geral um grito contra a religião oficial das monarquias e seus centros de culto, nos quais a ostentação de altares caros e deuses de metal fundido, ou mesmo de ouro e de prata, tinham a função de legitimar a exploração das famílias camponesas (Os 8,4-5; 13,2; cf. Lv 19,6; Dt 9, 12. 16; 27,15; 1Rs 14,9; Is 30,22)."
} 
Como já foi comentado, antes das reformas as leis contra imagens não tinham o mesmo propósito dos discursos teológicos que atualmente condenam as pessoas, os povos, as religiões, ao utilizarem imagens em seus cultos. Em Israel, no período pré-exílico, as vilas camponesas mantinham em seus locais de culto, altares de terra, imagens de madeira, de pedra, de cerâmica. É importante destacar que nesses rituais litúrgicos e nesses vilarejos "ninguém ficava mais rico ou mais pobre." Os cultos estavam ligados diretamente às necessidades concretas da vida e não ao acúmulo de riqueza e poder. Portanto, é possível questionar se a "idolatria" está presente no culto que utiliza diversos deuses, deusas e imagens, todas elas ligadas a defesa da vida, ou no culto centralizado em um só lugar, um só Deus, mas que não está ligado à promoção da vida, por permitir a exploração e opressão.

É muito provável que o alerta desses profetas camponeses tenha contribuído para a constituição das leis de Israel, especialmente, nas reformas de Ezequias e Josias. Outro fato perceptível e comentado por Dietrich (2015, p. 354) é o "lado ambíguo da religião oficial: leis que na origem eram contra o acúmulo de riqueza e de poder realizado pela monarquia, integradas nas reformas eram postas a serviço da monarquia e visavam dar-Ihe legitimidade." Isso deve levar a uma reflexão quando se abordam outras religiões que utilizam imagens em seus cultos, especialmente no Brasil, as mais perseguidas: as afro-brasileiras, as indígenas e as populares. Em muitas ocasiões, a condenação dessas religiões dá a impressão de estar carregada do mesmo espírito centralizador e opressor que esteve presente nas reformas concentradoras de riqueza e poder comandadas por Ezequias e Josias. É primordial deixar de lado o espírito conservador, imperialista e, perante a diversidade dos ritos religiosos, buscar o respeito e a convivência pacífica para entender o que é adorar a Deus.

\section{A idolatria e o culto a imagens}

A adoração de imagens no período politeísta representando suas divindades fazia parte da religiosidade, da cultura e da tradição, especial- 
mente no Egito, Síria e Mesopotâmia. As divindades se faziam presentes no cotidiano das pessoas e eram invocadas para favorecer uma colheita, aumentar o rebanho, proteger a família, garantir a justiça. Elas acreditavam que essa era a maneira adequada de prestar culto e receber a proteção de um deus. Um exemplo dessa proteção é a narrativa de Gn 31,49, já mencionada, na qual Raquel roubou os terafins que pertenciam a seu pai Labão antes de sair da sua casa, como símbolo de proteção e de justiça.

A proibição do culto às divindades e a produção das imagens que as representassem teve origem para o povo de Israel na revelação de Deus a Moisés no monte Sinai. Inclusive, não era permitido fazer imagens do próprio Javé. A revelação de Deus a Moisés no Sinai estabeleceu o conceito de idolatria. A monolatria em Israel foi um processo lento principalmente até o período do rei Josias no qual Javé foi reconhecido como o único Deus. No princípio, Javé era apenas um dos deuses cultuado, somente depois é que ficou reconhecido como o único deus, o Deus dos pais, de Abraão, de Isaac, de Jacó, o Deus criador de tudo"1.

A proibição do culto às imagens na Bíblia ocorre em função do ídolo (imagem) não ser deus e ter sido produzido por mão humana. A idolatria é um processo no qual se concebe a uma imagem uma função divina que não possui. Segundo Mckenzie (2003, p. 436), nesse sentido, nenhuma “ figura humana ou de animal poderia representá-lo. Representar Javé por meio de imagens seria o mesmo que o reduzir ao nível da natureza e, por conseguinte, rebaixá-lo ao nível de divindades adoradas por imagens". Mesmo sabendo qual era a vontade de Deus de não construir imagem que o representasse e não prestar culto a outra divindade, por que em momentos específicos da história, a lei não foi cumprida e se voltou a cultuar imagens? Como forma de entender esse retrocesso histórico, é oportuna

\footnotetext{
"Na narrativa do texto bíblico Ex 20, 3-5 é possível constatar: "não tenha você outros deuses diante de mim. Não faça para você imagem de deus, qualquer representação do que existe no céu, na terra ou nas águas que estão debaixo da terra. Não se prostre diante desses deuses, não lhes sirva, porque eu, Javé seu Deus, sou um Deus ciumento."
} 
a análise de duas narrativas bíblicas, amplamente conhecidas e dotadas de grande clareza que facilitará um entendimento mais aprofundado.

A primeira narrativa bíblica refere-se ao bezerro de Aarão. $\mathrm{O}$ texto discorre sobre quando Moisés subiu a montanha para se encontrar com Deus. Durante a subida, o povo permaneceu embaixo aguardando o retorno de Moisés que segundo o texto bíblico (Ex 24,18), demorou quarenta dias. Tempo suficiente para o povo se sentir sozinho, desamparado, sem liderança. O período de quarenta dias pode representar o simbolismo de um tempo suficiente para um encontro com Deus e de preparação para o novo momento histórico. Outra interpretação simbólica encontra amparo no texto quando Moisés se encontra com Deus no alto da montanha, enquanto o povo permanece embaixo, desamparado e desprovido de uma divindade. A inquietação e reclamação do povo não tardam a aparecer, conforme Ex 32,1: “... porque não sabemos o que aconteceu com esse Moisés, o homem que nos tirou da terra do Egito". O povo ainda não reconhece em Moisés como o enviado por Deus, o Profeta da Lei, aquele que foi encarregado para liderá-los. Até então, é apenas "esse Moisés".

Outro elemento é que o povo não percebe que é o Senhor Javé quem os libertou do Egito e que permanece junto na caminhada como o Deus libertador. Quando se sente desamparado e perdido, pede a Aarão uma divindade para protegê-los: Ex 32,1 - "Vamos! Faça para nós deuses que caminhem à nossa frente". É preciso destacar que nesse período o culto é politeísta e o povo não quer viver sem a proteção de uma divindade. Sente a necessidade de ter Elohim ${ }^{12}$ concreto, presente e que conforme narra o versículo, "que caminhem à nossa frente". O povo solicita a confecção de deuses para Aarão e, para não entrar em conflito, atende o pedido. O pecado do povo está na impaciência de não esperar o retorno de Moisés. O bezerro de ouro foi celebrado com altar, festa, comida e bebida, como se fosse o Senhor Javé. A narrativa do texto

\footnotetext{
12 O termo hebraico Elohim é utilizado no plural, traduzido por deuses. Embora muitas vezes é, também, empregado no singular, como deus. No caso do versículo em discussão, o termo é traduzido no plural embora seja apenas um bezerro, é possível interpretar como uma representação de um grupo de deuses (TOGNERI, 2015, p. 368).
} 
bíblico Ex 32,22-24 deixa visível os motivos e a intenção de atribuir a culpa ao povo, a confecção do bezerro de ouro, conforme explicação para Moisés:

Não fique irritado meu Senhor. Você sabe que este povo é inclinado para o mal. Eles me pediram: "Faça para nós deuses que caminhem à nossa frente, porque não sabemos o que é feito desse Moisés, o homem que nos tirou da terra do Egito". Eu disse então: “Quem tiver ouro, que o retire". Eles me trouxeram, eu levei ao fogo, e saiu esse bezerro.

Quando Moisés subiu à montanha o povo ficou sem liderança e, até o momento, Moisés era o líder que tinha a ligação com o Senhor Javé, diferente de Aarão que não desfrutava dessa intimidade. Segundo Togneri (2015, p. 369), "o texto culpa totalmente o povo pela quebra e ruptura da Aliança com o Senhor. Esse relato nos lembra da frase e da ação de Jesus, muito tempo depois, ao olhar a multidão e se compadecer deles (do povo) (Mc 6,34)." O que está por trás da narrativa é a incompreensão do povo no Deus libertador. Precisa de um tempo maior para entender os desígnios de Javé. Isso se percebe ao substitui-lo por uma imagem de metal fundido, um bezerro'13 de ouro, moldado por Aarão, do ouro que o povo deu, retirado dos brincos que tinham nas orelhas. Depois de criado, o povo disse: "Israel, este são os deuses, que tiraram você da terra do Egito." (Ex 32,4)14

\footnotetext{
13 A tradução do termo hebraico 'egel' por bezerro, segundo Togneri (2015, p. 370), não é fiel em virtude do termo se referir a um jovem touro com aproximadamente três anos de idade. Deve-se considerar o fato de o povo estar no deserto e é muito improvável que tenham animais de grande porte, mesmo assim tem como imagem protetora um bezerro, "ou um pequeno touro". Togneri indica a possibilidade de "ser fruto do culto a Apis ou à deusa Hator desenvolvido no Egito?" Existe a possibilidade de Aarão ser natural do Egito e, talvez, esses deuses, o tenham inspirado na fabricação do bezerro de ouro. Togneri, também menciona a interpretação de Cole (1981, p. 207) sobre essa questão: "a santidade do touro como símbolo de força e capacidade reprodutiva corre desde o culto a Baal em Canaã até o hinduísmo popular do sul da Índia de hoje, onde quer que a religião seja vista como forma do culto da fertilidade comum aos criadores de animais.

14 Outra interpretação sobre a atitude de Aarão que merece destaque é a desenvolvida por Adiñach (2010, p. 362): "a atitude de Aarão pode ser vista como tentativa de criar uma religião a partir dos desejos das pessoas e não a partir da palavra revelada. Uma religião que não se fundamenta na pergunta 'O que Deus espera de nós?' mas na interrogação 'Qual Deus as pessoas querem ter?'”.
} 
Outro fato para entender o culto politeísta do povo de Israel está na narrativa de Ex 12,38: "junto com os filhos de Israel, subiu também com eles grande mistura de gente". Durante o exílio uniram-se ao povo de Israel muitas outras pessoas que traziam consigo a prática da cultura religiosa a diversas divindades representadas por imagens e o bezerro de ouro pode ser um exemplo disso. Também é preciso considerar o período em que a narrativa foi escrita, bem posterior aos acontecimentos e, por isso, carregada com o sentimento de pecado, quando ainda o povo não tinha consciência de quem era o Javé.

A segunda narrativa bíblica é sobre os dois bezerros de Jeroboão (1Rs 12,26-33). O texto está relacionado à época da divisão da monarquia em reino do Sul - Judá, sob o reinado de Roboão, e reino do Norte - Israel, comandado por Jeroboão em torno de 930 a. C. O povo do Norte, sob a influência de Jeroboão, deve ter adquirido o apoio dos anciões das 10 tribos para romper com a tradição do Sul de rejeitar o Templo de Jerusalém e, também, suspender as peregrinações para as grandes festas na capital dourada. Havia sido determinado pelas tábuas da Lei na Arca da Aliança que o povo se apresentasse em sua honra, por ocasião a três festejos em Jerusalém: na Festa da Páscoa (celebração da saída do Egito e dos Pães sem Fermento), na Festa de Pentecostes (celebração da colheita) e na Festa das Tendas (celebração do final do período agrícola).

Com o propósito de evitar que o povo do Norte se dirigisse ao Templo de Jerusalém (CHAMPLIN, 2000, p. 1411) que era grandioso, preocupado por Judá ser um lugar com uma religiosidade especial e impedir que o povo passasse a seguir o Rei Roboão, Jeroboão mandou construir dois bezerros de ouro e os colocou em dois santuários de forma estratégica. A distância que os dividia era em torno de 160 quilômetros. Em Dã, no Norte, sopé do Monte Heron, favorecia o deslocamento das tribos do Norte de Israel e, em Betel, no Sul, apenas 20 quilômetros de Jerusalém, entre os territórios de Efraim e Benjamim (TOGNERI, 2015, p. 372). Os bezerros foram denominados por Jeroboão como: "os deuses que fizeram vocês sair da terra do Egito" (1Rs 12,28). 
Parece claro que a intenção de Jeroboão era afastar o seu povo da influência do governo do Sul a fim de proteger o seu reinado, pois tinha receio de perder o apoio da população e até mesmo, a sua vida, conforme a narrativa bíblica:

Jeroboão disse em seu coração: “Agora mesmo o reino poderá voltar para a casa de Davi. Se este povo subir e oferecer sacrifícios na casa de Javé em Jerusalém, seu coração vai se virar para seu senhor Roboão, rei de Judá. Eles acabarão me matando e passando para o lado de Roboão, rei de Judá (1Rs 12,26-27).

Nesse caso é preciso considerar, segundo Togneri (2015, p. 371), o fato do reino do Norte desejar sua própria religiosidade a fim de manter o povo sob o jugo de Jeroboão. As estratégias utilizadas foram construir os bezerros de ouro, reconstruir os templos de Betel e Dã, comemorar a Festa das Tendas, com data diferente da de Judá, e criar novo sacerdócio. Tudo com a intenção de manter independência da tradição religiosa do reino do Sul. Pela tradição, Jeroboão não podia ter iniciado o culto em Dã e Betel, fazendo com que o povo fosse em procissão cultuar os bezerros, recaindo em uma situação de pecado. Não era lícito celebrar a Páscoa e outras festas fora do domínio de Jerusalém, como também, não podia alterar o calendário das festas. A quebra dessa tradição, para Crocetti (1994, p. 117), tornava o culto em Israel idolátrico.

Diante do exposto, é possível fazer algumas considerações sobre as duas narrativas bíblicas, permanecendo fiel ao propósito de identificar a idolatria como um processo de dominação e exploração do povo, por reis dominadores, que se utilizam da criação de uma divindade para legitimar a opressão e interferir na comunidade humana. A primeira é que o poder atribuído a Deus acabou por legitimar o poder absoluto do autoritarismo, da ditadura e dos impérios na terra. A outra, é que o símbolo da grandeza de Deus serviu para justificar o poder e o desejo ilimitado dos homens.

O relevante na primeira narrativa é que o bezerro de Aarão foi solicitado pelo povo que permanecia impaciente com a ausência de Moisés, com sentimento de abandono e desejoso de um deus que caminhasse à sua frente. A 
construção do bezerro de Aarão foi fruto da participação do povo, feito com os brincos de ouro que traziam nas orelhas. Enquanto, na segunda narrativa, os dois bezerros de Jeroboão (ok)foram feitos por iniciativa própria, criados pelo medo da morte e da perda do poder, ou seja, impostos por Jeroboão, mesmo com a conivência das dez tribos do Norte. As imagens dos bezerros tinham a intenção de representar os deuses que os tiraram do Egito, por conseguinte, não reconheciam Javé como Deus libertador. O povo não teve a participação direta na construção dos bezerros, nem forai consultado, embora o ouro utilizado possa ter sido resultado da exploração e do jugo desse povo.

Na narrativa de "Ex 32,1-10 o povo é ativo e em 1 Rs 12,26-33 o povo é passivo" (TOGNERI, 2015, p. 373). Na primeira narrativa o povo se sente só, abandonado, solicita um deus que caminhe à sua frente. Na segunda, é o rei Jeroboão que teme ficar isolado, perder o apoio do povo e sua própria vida. Para se proteger, oferece uma representação de Deus, com imagens representando divindades. É possível perceber na narrativa que o povo não se revolta com a mudança na tradição religiosa imposta por Jeroboão, pois foi ele quem decidiu onde seriam colocados os bezerros. O povo se deixa dominar e passa a frequentar em peregrinação os santuários de Betel e Dã, como também aceita a alteração das datas festivas. Na verdade, tornaram-se uma nação tão morta espiritualmente quanto os ídolos que passaram a adorar.

No entanto, a construção dos bezerros e a entrega ao povo teve o mesmo sentido para o povo e para Jeroboão: "Israel, estes são os seus deuses que tiraram você da terra do Egito" (Ex 32,4: 1Rs 12,28). Isso significa que o povo ainda não reconhecia Javé como o Deus libertador, necessitava de imagens, deuses visíveis. A dificuldade estava em acreditar no Senhor Javé, Deus libertador invisível, que se revela através da palavra e de ações e que não pode ser comparado e representado por nenhuma imagem.

\section{A questão idolátrica no Cristianismo}

Ao ler a Bíblia facilmente surge o seguinte questionamento: qual Deus é o verdadeiro? Existe o reconhecimento que Deus é profundamente "hu- 
mano", vivo e ao revelar seu nome em Ex 3,14 deixa claro: “Eu sou aquele que é". ${ }^{15}$ Deus se mostra como absoluto ${ }^{16}$.

A Bíblia também relata que "somos a imagem e semelhança de Deus" e que Deus é bondade, amor, justiça. Portanto, permanecendo fiel ao relato, o homem deveria praticar a bondade, o amor a justiça. No entanto, o que se percebe é que não é bem assim. "Fizemos Deus à nossa imagem e semelhança. O ser humano cria a sua própria divindade e a adora como sua própria imagem" (CLÓVIS; BERNARDINO, 2015, p. 396). Segundo o exposto, o Deus que se vê, reflete aquilo que se é. Assim, a sociedade contemporânea violenta, possivelmente terá deuses violentos.

Desde os tempos antigos quando o "Deus de Abraão, o Deus de Isaac, o Deus de Jacó" foi substituído por outros deuses, as religiões procuram

15 O texto de $E x$ 3,14 apresenta diferentes traduções, interpretações e inúmeros debates. Por exemplo, a Bíblia do Peregrino, edições Paulinas, traduz Ex 3,14 como "Sou o que sou". A opção foi seguir a tradução da Bíblia de Jerusalém: "Eu sou aquele que é". É enriquecedor o comentário que a Bíblia de Jerusalém apresenta sobre Ex 3,14. "Essa narrativa, é um dos pontos altos do AT, coloca dois problemas: o primeiro filosófico, diz respeito à etimologia do nome 'lahweh'; o segundo exegético e teológico, o sentido geral da narrativa e o alcance da revelação que transmite. $1^{\circ}$ Procura-se explicar a nome de lahweh através de outras línguas que não fossem o hebraico, ou então através de diversas raízes hebraicas. É preciso, provavelmente, ver aí o verbo 'ser' numa forma arcaica. Alguns reconhecem aqui uma forma causativa deste verbo: 'Ele faz ser', 'Ele traz a existência'. Muito mais provavelmente trata-se de uma forma do tema simples, e o termo significa: 'Ele é'. $2^{\circ}$ Quanto à interpretação, o termo é explicado no v. 14, que é um antigo acréscimo da mesma tradição. Discute-se sobre o significado desta explicação: 'ehyeh' 'asher' ehyeh'. Deus, falando de si mesmo, só pode empregar a primeira pessoa: 'Eu sou'. O hebraico pode ser traduzido literalmente: 'Eu sou o que sou'. Isso significaria que Deus não quer revelar o seu nome. Mais precisamente, Deus dá aqui o seu nome que, segundo a concepção semita, deve defini-lo de certa maneira. Contudo, o hebraico pode ser também traduzido literalmente: 'Eu sou aquele que sou'; e segundo as regras de sintaxe hebraica, isso corresponde a 'Eu sou aquele que é', 'Eu sou o existente'. Foi assim que compreenderam os tradutores da Setenta: Ego, eimi ho ôn. Deus é o único verdadeiramente existente. Isto significa que ele é transcendente e permanece um mistério para o homem. E, além disso, ele age na história do seu povo e na história humana, a qual ele dirige para um fim. Esta passagem contém em potência os desenvolvimentos que a sequência da Revelação Ihe dará (Cf. Ap 1,8: 'Aquele-que-é, Aquele-que-era e Aquele-que-vem, o Todo Poderoso'”). (Cf. BÍBLIA DE JERUSALÉM, 1985).

16 Sobre esse sentido absoluto, é oportuno o comentário de Gutiérrez (1990, p. 36-37): "ser princípio absoluto não significa desinteressar-se pela história. Pelo contrário, ao revelar seu nome, que não é puro conceito, Javé manifesta a sua decisão de participar dela. O ser de Deus está ligado no decurso histórico. O eterno se faz presente no temporal, o absoluto na história, sem ser, porém, apenas uma presença: é também comunhão, é dom [...] 'Eu sou' (Javé) princípio absoluto e ativo, origem de tudo, é igualmente o Deus do passado, o Deus dos patriarcas, dos antepassados, daqueles aos quais Moisés agora é enviado". 
apresentar o Deus verdadeiro e oferecer uma proposta segura de salvação. Muitas se apresentam como a verdadeira, a única, acusando as outras de falsas, ao mesmo tempo que templos são erguidos, novas propostas religiosas são ofertadas. No entanto, apesar da bonita retórica, desconhecem o Deus do qual o homem é "imagem e semelhança", "mesmo falando deste Deus, vão criando para o povo ídolos que não salvam e não são capazes de ouvir o clamor dos pobres" (CLÓVIS; BERNARDINO, 2015, p. 396).

Com um olhar atento sobre o Novo Testamento é possível perceber que ídolo para Jesus é uma realidade histórica concreta e diretamente vinculada ao dinheiro, como, por exemplo, no Evangelho de Mateus: "Ninguém pode servir a dois senhores. Com efeito ou odiará um e amará o outro, ou se apegará ao primeiro e desprezará o segundo. Não podeis servir a Deus e ao Dinheiro" (Mt 6,24). Também no Evangelho de Lucas a narrativa é praticamente a mesma: "Ninguém pode servir a dois senhores: com efeito, ou odiará um e amará o outro. Ou se apegará a um e desprezará o outro. Não podeis servir a Deus e o Dinheiro" (LC 16,13). Portanto, a questão dos ídolos vai além da veneração das imagens criadas. O tema refere-se aos amantes do dinheiro, que acumulam e guardam seu tesouro como se fosse algo divino, acreditando ser fonte de bênção e felicidade. É justamente o que o Apóstolo Paulo denuncia: o dinheiro é um ídolo. Assim, os ídolos não se limitam apenas ao culto das imagens, mas também se referem a atitudes do coração.

Transformar o dinheiro em poder soberano é o mesmo que negar o Deus da vida, da vida dos pobres, dos que não têm dinheiro. À sombra da idolatria se esconde e legitima a opressão das pessoas, especialmente das mais pobres; oculta-se a justiça trazendo consequências imediatas e reais sobre essas pessoas, como por exemplo, a injustiça, a ganância, a maldade e o assassinato. O tema transparece na carta aos Romanos: "Manifesta-se, com efeito, a ira de Deus, do alto do céu, contra toda impiedade e injustiça dos homens que mantêm a verdade prisioneira da injustiça..." (Rm 1,18-32).

Os Evangelhos apresentam Deus com várias denominações, como Emanuel, o Deus conosco (Mt, 1,23), o Deus justo (Rm 9,14), um Deus fiel 
(1Cor 1,9). No entanto, a síntese de tudo encontra amparo na expressão: "Deus é amor" (1/o 4,18). O povo ao experimentar o amor de Deus, é convidado a abandonar os ídolos e a servir o Deus vivo e verdadeiro (1Ts 1,9). Deus vivo no sentido que a revelação tem a ver com a vida, Ele cria e defende a vida. Idolatria é a manipulação de Deus, é criar uma realidade na qual se coloca a confiança em alguém ou alguma coisa que não é Deus.

Assim como na história de Israel o problema da idolatria foi uma constante, o mesmo acontece no cristianismo. Facilmente o Deus da vida apresentado por Jesus é trocado por um simulacro divino, produto humano que provoca opressão e sofrimento nas pessoas. Clóvis e Bernardino (2015, p. 401) destacam que "nenhum sistema religioso é fiel a Deus se permite a exploração ou a negação da dignidade do ser humano." Aceitar a injustiça social, a fome, a violência, ações que desrespeitam a vida e o meio ambiente constitui uma prova que falsos deuses são adorados, encobertos pelo véu do egoísmo, do individualismo do poder econômico. $\mathrm{O}$ ídolo provoca uma fascinação que em certas ocasiões passa a impressão que suas "propostas" são mais palatáveis que as do Deus bíblico. No entendimento de Keller (2016, p. 15) a idolatria manifesta-se quando "um ídolo tem uma posição de controle tão grande em seu coração que você é capaz de gastar com ele a maior parte de sua paixão e energia, seus recursos financeiros e emocionais, sem pensar duas vezes".

O cenário religioso do Império Romano apresentava um conjunto de deuses espalhados por todo Império no qual Estado e religião se confundiam. As autoridades públicas eram responsáveis pela organização da religião oficial e, a fim de manter a legitimidade nas relações sociais e políticas, os imperadores se autodivinizavam proclamando-se deuses e passando a exigir de seus súditos o devido culto. Essa estrutura da sociedade Romana provocou enorme dificuldade no início do cristianismo em função de não se admitir questionamentos sobre a religião e ritos em prol dos imperadores. O fato de Jesus anunciar o Reino de Deus e, no seu "projeto político", assumir a defesa dos pobres, dos doentes, dos marginalizados, questionando o desrespeito à vida, provocou um enfrentamento com o Império Romano. Contestar a 
religião do Império consistia em colocar-se contra o Estado e, em virtude disso, no princípio houve um confronto ideológico, posteriormente, um embate jurídico, até culminar na morte de Jesus e na perseguição dos cristãos.

Atualmente é o sistema capitalista neoliberal que assume o papel do Império Romano ao transferir o plano do Deus da vida para o mercado que privilegia alguns indivíduos através do sacrifício da maioria. A idolatria tem a função simbólica de legitimar a opressão do poder econômico vigente e político. Isso é facilmente percebido quando o ídolo passa a ser mais importante que o homem, tornando-o explorado e dominado.

\section{Considerações finais}

O problema da idolatria na revelação bíblica, cuja interpretação não pode estar ancorada no fundamentalismo e na intolerância, está em camuflar a nobreza entre Deus, o Criador, e a criatura. Todo poder atribuído a Deus acabou por legitimar o poder absoluto do autoritarismo, da ditadura e dos impérios na terra. Serviu para justificar o poder e o desejo ilimitado dos homens. Um processo que culminou na dominação e na exploração do povo por reis dominadores que se utilizaram da criação de uma divindade para legitimar a opressão. Assim, foi possível depreender que a idolatria pode ser qualquer realidade divinizada pelo homem; ela se constitui ao substituir o divino por algo que se possa manipular e usar. À sombra da idolatria se esconde e se legitima a opressão, especialmente dos mais pobres, e se oculta a justiça trazendo consequências imediatas e reais como a ganância, a maldade e a exclusão.

Foi possível corroborar, também, que a idolatria é uma divindade que oprime e exige a entrega e o sacrifício humano; outro ponto demonstrado foi que os ídolos são deuses que legitimam a opressão, apoiam poderes dominadores, interferem na comunidade humana e são incapazes de ouvir o clamor dos pobres. O sacrifício exigido não é mais em nome de Deus, mas de uma instituição que foi transcendentalizada. É o caso do mercado que se utilizou da religião como instrumento para justificar e legitimar o projeto econômico de expansão, dominação e opressão. 


\section{Referências}

ADIÑACH, Pablo R. O livro do Êxodo. Um comentário exegético-teológico. São Leopoldo: EST, 2010. https://doi.org/10.25188/flt-voxscript(eissn2447-7443) vxxi.n2.p208-214.rmw

ASSMANN, Hugo. Desafios e falácias: ensaios sobre a conjuntura atual. São Paulo: Paulinas, 1991.

ASSMANN, Hugo. A Teologia da Libertação se opõe aos ídolos da opressão. In: ALVES, Rubem et al. Fé cristã e ideologia. São Bernardo do Campo: Unimep Imprensa Metodista, 1981.

ASSMANN, Hugo. Deus em nós: o reinado que acontece no amor solidário aos pobres. São Paulo: Paulus, 2010.

ASSMANN, Hugo; HINKELAMMERT, Franz J. A idolatria do Mercado: ensaio sobre Economia e Teologia. São Paulo: Vozes, 1989. (Série V: desafios da vida na sociedade).

BEALE, G, K. Você se torna aquilo que adora: uma teologia bíblica da idolatria. São Paulo: Vida Nova, 2014.

BERGER, Peter Ludwig. O dossel sagrado: elementos para uma teoria sociológica da religião. São Paulo: Paulus, 1985.

BÍBLIA DE JERUSALÉM. São Paulo: Edições Paulinas, 1985.

BÍBLIA DE TRADUÇÃO ECUMÊNICA, TEB. São Paulo: Loyola, 1994.

BÍBLIA DO PEREGRINO. São Paulo: Paulus, 2002.

BÍBLIA SAGRADA. Tradução da CNBB. Petrópolis: Vozes, 2001.

BOFF, Leonardo. Teologia do cativeiro e da libertação. Petrópolis: Vozes, 1980.

CHAMPLIN, Russel Norman. O Antigo Testamento interpretado. Versículo a versículo. São Paulo: Candeia, 2000.

CLÓVIS, Benedito; BERNARDINO, Orides. Os "ídolos" no cristianismo primitivo. Petrópolis: Vozes, 2015. Também publicado em: Estudos Bíblicos, Petrópolis, v. 31, p. 395-404, out/dez. 2014.

COLE, R. Alan. Êxodo. Introdução e comentário. São Paulo: Edições Vida Nova; Mundo Cristão, 1981.

CROCETTI, Guiseppe. 1 e 2 Samuel, 1 e 2 Reis. Pequeno Comentário AT. São Paulo: Paulus, 1994. 
COELHO, Allan da Silva. O Capitalismo como Religião: Uma crítica a seus fundamentos mítico-teológicos. 2014. 281 f. Tese (doutorado). São Bernardo do Campo: Universidade Metodista de São Paulo, 2014. https://doi.org/10.11606/t.42.2019.tde-12042018-141555

DIETRICH, Luiz José. Quando as imagens viram ídolos. Petrópolis: Vozes, 2015. Também publicado em: Estudos Bíblicos, Petrópolis, v. 31, n. 124, p. 341-354, out./dez. 2014.

DUSSEL, Enrique. Ética comunitária. Série III: A libertação na história. Petrópolis: Vozes, 1994.

DUSSEL, Enrique. Filosofia da libertação: Crítica à ideologia da exclusão. São Paulo: Paulus, 1995.

FERREIRA, Franklin. Contra a idolatria do Estado: o papel do cristão na política. São Paulo: Vida Nova, 2016.

FROMM, Erich. O Conceito Marxista do Homem. 8. ed. Rio de Janeiro: Zahar, 1983. GUTIÉRREZ, Gustavo. O Deus da vida. São Paulo: Loyola, 1990.

HINKELAMMERT, Franz. A maldição que pesa sobre a lei: As raízes de pensamento crítico em Paulo de Tarso. São Paulo: Paulus, 2012.

HINKELAMMERT, Franz. Mercado versus direitos humanos. São Paulo: Paulus, 2014. HINKELAMMERT, Franz. Crítica a la razón utópica. San José: DEI, 1984.

HINKELAMMERT, Franz. As armas ideológicas da morte. São Paulo: Paulinas, 1983. HINKELAMMERT, Franz. La fe de Abraham y el Edipo Occidental. San José: DEI, 1989.

HINKELAMMERT, Franz. Sacrifícios Humanos e Sociedade Ocidental: Lúcifer e a Besta. São Paulo: Paulus, 1995.

KELLER, Timothy J. Deuses falsos: como resistir às idolatrias que prometem o mundo, mas cobram um preço alto demais. Rio de Janeiro: Thomas Nelson Brasil, 2016.

LÖWY, Michael. A guerra dos deuses: religião e política na América Latina. Petrópolis: vozes, 2000. https://doi.org/10.5380/his.v38io.2721

LÖWY, Michael. O capitalismo como religião: Walter Benjamin e Max Weber, In: JINKINGS, I; PESCHANSKI, J. (org.). As utopias de Michael Löwy: reflexões sobre um marxista insubordinado. São Paulo: Boitempo, 2007. p. 177-190. https://doi.org/10.4067/s0718-65682014000200032 
MANNHEIM, Karl. Ideologia e utopia. Rio de Janeiro: Zahar, 1968.

McKENZIE, John L. Dicionário Bíblico. São Paulo: Paulus, 2003.

MENENDEZ UREÑA, Enrique. O mito do cristianismo socialista. São Paulo: Edições Loyola, 1982.

OTTO, R. O sagrado: Sobre o Irracional na ideia do Divino e sua Relação com o Irracional. Lisboa: Edições 70, 1992.

PADILLA, René C. Deus e mamon: economia do Reino na era da globalização. Rio de janeiro: Novos Diálogos. 2011.

RICHARD, Pablo et al. A luta dos deuses: Os ídolos da opressão e a busca do Deus libertador. São Paulo: Paulinas, 1982.

RICHARD, Pablo. Morte das Cristandades e nascimento da Igreja. Análise histórica e interpretação teológica da Igreja na América Latina. São Paulo: Paulinas, 1984.

SICRE DÍAZ, José Luis. Introdução ao profetismo bíblico. Petrópolis RJ: Vozes, 2016. SUNG, Jung Mo. Cristianismo de libertação: espiritualidade e luta social. São Paulo: Paulus, 2008.

SUNG, Jung Mo. A idolatria do capital e a morte dos pobres: uma reflexão teológica a partir da dívida externa. São Paulo: Edições Paulinas, 1989.

SUNG, Jung Mo. Desejo, mercado e religião. Petrópolis: Vozes, 1997.

SUNG, Jung Mo. Teologia e Economia: repensando a teologia da libertação e utopias. Petrópolis, RJ: Vozes, 1994.

SUNG, Jung Mo. Idolatria: uma chave de leitura da economia contemporânea? In: BRITO, Enio J. C.; GORGULHO, Gilberto S. (org.). Religião ano 2000. São Paulo: Loyola- CRE PUC-SP, 1998.

SUNG, Jung Mo. Mercado religioso e mercado como religião. Horizonte, Belo Horizonte, v. 12, n. 34, p. 290-315, abr./jun. 2014. https://doi.org/10.5752/p. 2175-5841.2014V12n34p290

SUNG, Jung Mo. Sujeito e sociedades complexas. Petrópolis; Vozes, 2002.

TOGNERI, Silvia. Os Bezerros de ouro. Estudo de Ex 32,1-10 e 1Rs 12,25-33. Petrópolis: Vozes, 2015. Também publicado em: Estudos Bíblicos, Petrópolis, v. 31, n. 124, p. 365-374, out./dez. 2014.

ZAMORA, José Antonio. Religión y fetichismo de la mercancia. In: MOREIRA, Alberto da Silva (org.). Capitalismo como religião. Goiana: PUC, 2012. 


\section{Endereço postal}

Jair Inácio Tauchen

Pontifícia Universidade Católica do Rio Grande do Sul - (PUCRS)

Programa de Pós-Graduação em Filosofia

Av. Ipiranga, 6681 - Prédio $8-4^{\circ}$ andar - Sala 403.

CEP 90.619-900 - Partenon, Porto Alegre, RS - Brasil. 